\title{
NEGÓCIOS NA BASE DA PIRÂMIDE
}

Base da Pirâmide é um assunto relativamente recente no mundo dos negócios e ainda bastante controverso. Desde o final da década de 1990, acadêmicos e empresas buscam entender esse mercado e decifrar maneiras de acessá-lo, de forma a propiciar situações em que ganham empresa, consumidor e sociedade. Nesse sentido, as empresas podem obter maiores lucros e acessar uma população antes ausente do mercado de consumo. Os consumidores têm acesso a novos produtos e serviços, muitas vezes básicos. Além disso, negócios na base da pirâmide oferecem grandes impactos sociais, geração de renda e erradicação da pobreza. Modelos de negócios inclusivos, inovação, sustentabilidade, acesso a áreas remotas e com pouca infraestrutura, inclusão social, relacionamento e parcerias são alguns dos temas principais que abordam os livros indicados pelo Professor Edgard Barki da FGV-EAESP.
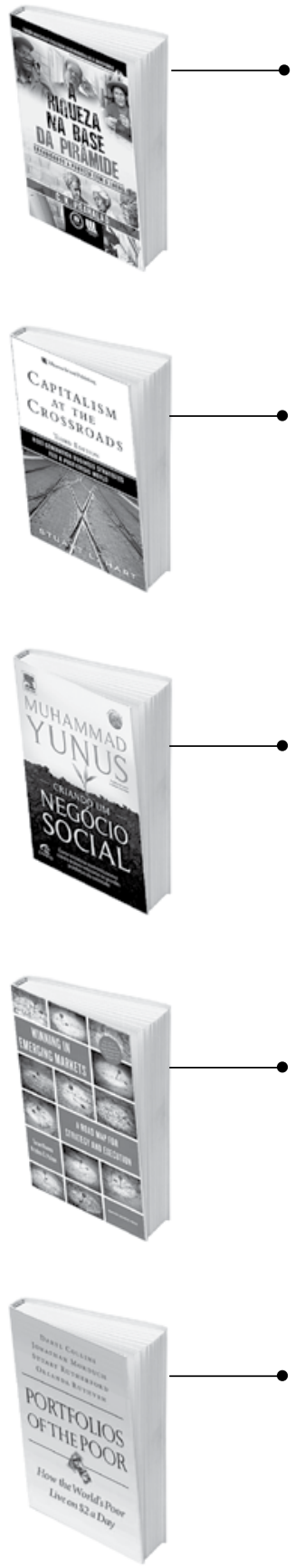

A RIQUEZA NA BASE DA PIRÂMIDE: Erradicando a pobreza com o lucro. C. K. Prahalad 2.ed. Porto Alegre: Bookman, 2009. 408 p.

A primeira edição deste livro é de 2004, sendo uma das publicações que mais influenciaram o mundo dos negócios para a base da pirâmide. O livro detalha como as empresas podem estabelecer negócios lucrativos na base da pirâmide, formada por 4 a 5 bilhões de pessoas. Destaca também a relevância da inovação e a influência negativa do ambiente de corrupção em países emergentes. Traz diversos casos, dentre os quais o das Casas Bahia.

CAPITALISM AT THE CROSSROADS: Next generation business strategies for a post-crisis world. Stuart L. Hart. 3. ed. New Jersey: Pearson Education, 2010. 322 p.

O livro discute o desafio de se criar um capitalismo mais inclusivo e sustentável ambientalmente. Hart defende que é possível aliar o conhecimento e as inovações em "tecnologia limpa" com modelos de negócios para a base da pirâmide. O autor sugere uma segunda geração de estratégias (BoP 2.0), usando um modelo de cocriação com a base da pirâmide, no qual as empresas desenvolvam "competências nativas" em parcerias com comunidades.

CRIANDO UM NEGÓCIO SOCIAL. Muhammad Yunus. Rio de Janeiro: Campus-Elsevier, 2010. 232 p.

Prêmio Nobel da paz em 2006, Muhammad Yunus descreve neste livro sua visão de Negócio Social, que tem como principal objetivo o impacto social e não o lucro (que deveria existir apenas como forma de sustentabilidade a longo prazo da empresa). Para o autor, os negócios sociais seriam a melhor (se não a única) alternativa para reverter a disparidade social existente no mundo. Descreve vários exemplos reais de negócios sociais, dentre os quais o famoso caso Grameen Danone.

WINNING IN EMERGING MARKETS: A road map for strategy and execution. Tarun Khanna e Krishna G. Palepu. Boston: Harvard Business Press, 2010. 247 p.

Este livro endereça as diferenças existentes na atuação empresarial em mercados emergentes, que apresentam importantes obstáculos para conectar de forma eficiente empresas e mercados. Descreve possíveis estratégias e as adaptações nos modelos de negócios das empresas que querem atuar nesses mercados. São apresentados diversos exemplos de grandes empresas que atuam em mercados emergentes, bem como o fenômeno das "Gigantes Emergentes": empresas que nasceram e cresceram em mercados emergentes e que agora se internacionalizam.

PORTFOLIOS OF THE POOR: How the world's poor live on \$2 a day. Daryl Collins, Jonathan Morduch,, Stuart Rutherford e Orlanda Ruthven. New Jersey: Princeton University Press, 2009. 283 p.

Este livro apresenta uma visão da população da base da pirâmide a partir de "diários financeiros" de pessoas que vivem com menos de US\$ 2 por dia na Índia, em Bangladesh e na África do Sul. Os autores identificaram como essa população utiliza seu escasso dinheiro, empresta e até poupa. Enfatizam a importância das redes informais e dos laços familiares e discutem a relevância de mecanismos de microfinanças e de "gerenciamento da renda". 